\title{
Analisis Kesalahan Siswa dalam Menyelesaikan Soal Matematika pada SMA Pedesaan dan SMA Perkotaan
}

\author{
1Yani Djawa, ${ }^{2}$ Satri Asma, ${ }^{3}$ Tamrin Taher \\ ${ }^{1}$ Jurusan Tadris Matematika, FTIK, IAIN Ternate \\ Jl. Lumba-Lumba, Kec. Ternate Utara, Maluku Utara,97727, Indonesia \\ Email:yani_diawa@yahoo.co.id
}

Article History:

Received: 13-08-2019; Received in Revised: 01-10-2019; Accepted: 28-10-2019

\begin{abstract}
Student errors in solving Mathematical problems are often found by writers in rural schools, and it possibly happened in schools in the city too. This article tries to analyze the mistakes of high school students in rural and urban areas in solving math problems. This research is qualitative with a research location in two schools, each as an interpretation of schools in rural and urban areas. The results found that students in a rural and urban school in principle there an error in solving problems. High school students in urban areas tend to make procedural errors while rural high school students in addition to making procedural errors also tend to make computational skills mistakes.
\end{abstract}

Keywords: Adversity Quotient; Mathematical Problem Solving; Polya.

\section{Abstrak}

Kesalahan siswa dalam menyelesaikan soal-soal Matematika sering penulis temukan pada sekolah di pedasaan, namun demikian tidak menutup kemungkinan juga terjadi pada sekolah di perkotaan. Artikel ini mencoba menganalisis kesalahan siswa SMA di Pedesaan dan Perkotaan dalam menyelesaikan soal matematika. Jenis penelitian yang digunakan adalah kualitatif dengan loaksi penelitian di dua sekolah yang masing-masing sebagai interpretasi sekolah yang berada di pedesaan dan perkotaan. Hasil penelitian diperoleh bahwa siswa yang bersekolah di pedesaan maupun perkotaan pada prinsipnya ditemukan adanya kesalahan dalam menyelesaikan soal. Siswa SMA di perkotaan cenderung untuk melakukan kesalahan prosedur sedangkan siswa SMA di pedesaan selain melakukan kesalahan prosedur juga cenderung melakukan kesalahan keterampilan komputasi.

Kata Kunci: Adversity Quotient; Pemecahan Masalah Matematika; Polya. 


\section{Pendahuluan}

Pendidikan diartikan sebagai suatu kegiatan yang sistematis dan sistemik terarah kepada terbentuknya kepribadian siswa. Sistematis oleh karena proses pendidikan berlangsung melalui tahap-tahap bersinambungan (prosedur) dan sistemik oleh karena berlangsung dalam situasi kondisi pada semua lingkungan yang saling mengisi baik lingkungan rumah, sekolah, dan masyarakat ${ }^{1}$.

Mata pelajaran matematika merupakan salah satu mata pelajaran yang diajarkan pada hampir setiap jenis dan jenjang pendidikan, mulai dari pendidikan dasar sampai dengan pendidikan tinggi, baik pendidikan umum maupun pendidikan kejuruan. Wujud dari mata pelajaran matematika menurut kurikulum pendidikan dasar dan menengah adalah berupa matematika sekolah. Matematika sekolah yaitu unsur-unsur atau bagianbagian dari matematika yang dipilih berdasarkan atau berorientasi kepada kepentingan kependidikan dan pengembangan IPTEK ${ }^{2}$.

Guru sebagai seorang pendidik dituntut untuk dapat menyelesaikan materi pembelajaran di sekolah sesuai dengan silabus yang telah ditentukan, sehingga kebanyakan pendidik menggunakan metode konvensional dalam mengajar untuk mengejar waktu yang telah direncanakan. Siswa yang mempunyai kemampuan menangkap pelajaran dengan cepat maka hal tersebut tidak jadi masalah tetapi sebaliknya pada siswa yang daya tangkapnya rendah, pada akhirnya mereka akan semakin kesulitan untuk memahami materi yang berikutnya, karena materi prasyarat yang mereka tempuh belum dikuasai ${ }^{3}$.

Kesulitan yang sering ditrmuai siswa dalam belajar adalah kesulitan dalam menyimpulkan informasi dari suatu konsep yang diberikan dan kesulitan dalam menyatakan suatu prinsip dan tidak mampu mengutarakan artinya dan menerapkannya ${ }^{4}$. Banyak faktor menyebabkan siswa memiliki kesulitan belajar, diantaranya yang pertama adalah faktor internal (dalam diri siswa), misalnya kemampuan yang dimiliki siswa, motivasi belajar, minat, perhatian, ketekunan, dan lain-lain. Faktor kedua adalah faktor eksternal (luar diri siswa), contohnya adalah guru, kurikulum, lingkungan, sarana dan prasarana. Salah satu faktor eksternal untuk mendapatkan

\footnotetext{
${ }^{1}$ Umar Tirtarahardja and La Sulo, Pengantar Pendidikan, Cet. 2 (Rineka Cipta, 2005).

${ }^{2}$ R. Soedjadi, Kiat Pendidikan Matematika Di Indonesia (Jakarta: Dirjen Dikti Depdikbud, 2000).

${ }^{3}$ Rahma Hidayati Darwis, "Eksplorasi Hasil Belajar, Aktifitas Siswa Dan Respon Siswa Pada Penerapan Metode Tutor Sebaya Dan Metode Kerja Kelompok Dalam Pembelajaran Remedial Matematika Meteri Trigonometri Pada Kelas XI SAP SMK Negeri 1 Watampone" (PhD Thesis, Thesis. Tidak Diterbitkan. Makassar: Pascasarjana Universitas Negeri Makassar, 2014).

${ }^{4}$ Andi Ika Prasasti Abrar, "Kesulitan Siswa SMP Belajar Konsep Dan Prinsip Dalam Matematika," Al-Khwarizmi: Jurnal Pendidikan Matematika dan Ilmu Pengetahuan Alam 2, no. 1 (2014): 59-68, https://doi.org/10.24256/jpmipa.v2i1.102.
} 
prestasi yang maksimal dan siswa tidak berkesulitan belajar adalah seseorang pendidik dituntut untuk sekreatif mungkin dalam menggunakan metode pembelajaran demi ketuntasan materi yang disampaikan. Lingkungan juga merupakan faktor eksternal yang menyebabkan siswa berkesulitan belajar, dan teman sebaya juga salah satu faktor lingkungan yang menyebabkan siswa berkesulitan belajar, setiap siswa harus kreatif dalam memilih teman bergaul, teman yang harus dipilih adalah teman yang berpandangan positif terhadap pelajaran, dan mau memberi dorongan untuk berprestasi dan belajar, karena itu sebagai faktor yang sangat mendukung untuk prestasinya. Carraher berargumen: bahwa mathematics has contributed in important ways to long standing debates about mathematical concepts, symbolic representation, and the role of contexts in thinking. Matematika berkenaan dengan konsep, representasi simbol dan aturan dalam konteks berpikir manusia ${ }^{5}$.

Dari hasil obeservasi awal, kesalahan siswa dalam menyelesaikan soal matematika khususnya soal Persamaan Kuadrat dan Pertidaksamaan Kuadrat sering di temukan pada sekolah-sekolah pedasaan, namun demikian tidak menutup kemungkinan pada sekolah-sekolah di perkotaan akan didapatkan hal demikian. Hasil belajar matematika siswa di desa dan di kota pada prinsipnya tidak berbeda secara signifikan. Hanya saja secara umum berdasarkan hasil ujian nasional di Kabupaten Madiun perbedaan hasil belajar tersebut berbeda secara signifikan ${ }^{6}$. Hasil belajar siswa yang berlatar sosial kota berada pada kategori yang sedikit lebih baik dibandingkan dengan siswa yang berlatar belakang sosial desa, meskipun secara signifikan tidak berbeda7. Banyak variabel yang dapat mempengaruhi gaya belajar siswa di kedua daerah. Variabel tersebut tergantung tempat tinggal siswa. Siswa yang tinggal di kota cenderung memiliki peluang dan sumberdaya yang lebih banyak untuk berprestasi dibandingkan dengan siswa yang tinggal di desa. Selain itu orang tua di kota lebih profesional dan mereka menyadari manfaat

${ }^{5}$ David Carraher, "Beyond 'Blaming the Victim' and 'Standing in Awe of Noble Savages': A Response to 'Revisiting Lave's "Cognition in Practice,"," Educational Studies in Mathematics 69 (September 1, 2008): 23-32, https://doi.org/10.1007/s10649-008-9126-4.

6 Agus Widi Agung, "Pengaruh Dana Bantuan Siswa Miskin Terhadap Prestasi Belajar pada Siswa Sekolah Menengah Pertama Se-Kabupaten Madiun Tahun 2011/2012” (Thesis, UNS (Sebelas Maret University), 2012), https://digilib.uns.ac.id/dokumen/25582/Pengaruh-DanaBantuan-Siswa-Miskin-Terhadap-Prestasi-Belajar-pada-Siswa-Sekolah-Menengah-Pertama-SeKabupaten-Madiun-Tahun-20112012.

7 Fitriati Fitriati, "Studi Perbandingan Prestasi Belajar Antara Siswa Yang Berlatar Belakang Sosial Kota Dengan Desa Pada Madrasah Tsanawiyah (Mts) Manba'ul 'Ulum Kertak Hanyar” (Skripsi, Banjarmasin, UIN Antasari Banjarmasin, 2013), https://idr.uinantasari.ac.id/2769/. 
pendidikan dibandingkan orang tua siswa pedesaan yang relatif cenderung tidak mengharapkan anak-anak mereka untuk melanjutkan pendidikan ${ }^{8}$

Berdasarkan uraian tersebut, untuk mengungkapkan faktor-faktor yang menyebabkan kesulitan atau kesalahan siswa dalam menyelesaikan soal matematika serta bagaimana mengatasi hal-hal tersebut maka penulis mengadakan penelitian pada salah satu sekolah yang ada di pedesaan dan perkotaan untuk memngetahui kemampuan siswa dalam pemahaman konsep, prosedur dan ketrampilan komputasi dalam menyelesaikan soal matematika bentuk uraian pada materi persamaan kuadrat dan pertidaksamaan kuadrat serta menemukan dan mengungkap penyebab kesalahan yang dilakukan siswa dalam menyelesaikan soal matematika bentuk uraian materi persamaan kuadrat dan pertidaksamaan kuadrat pada SMA di Perkotaan dan SMA di pedesaan berdasarkan hasil wawancara

\section{Metode}

Penelitian ini adalah penelitian kualitatif yang berusaha mengungkap fakta dalam menganalisis kesalahan siswa saat menyelesaikan soal matematika bentuk uraian khusus materi persamaan dan pertidaksamaan kuadrat baik pada SMA pedesaan maupun perkotaan pada Provinsi Maluku Utara. Penelitian ini dilakukan pada SMA Negeri 15 Halsel yang berlokasi di Desa Bibinoi Halmahera Selatan yang merupakan sekolah di pedasaan. Sedangkan SMA Negeri 4 Kota Ternate yang berlokasi di Kota Ternate dan merupakan salah satu sekolah di perkotaan.

Teknik pengambilan data dan instrumen penelitian yang digunakan dalam peneilitian sebagai berikut :

1. Instrumen Tes

Tes yang dimaksud adalah tes bentuk uraian. Tujuan pemberian instrument tes ini adalah untuk mengukur dan mengetahui sejauhmana kemampuan intelektual siswa dalam memahami konsep materi, prosedur-prosedur dalam menyelesaikan soal serta kemampuan keterampilan komputasi siswa baik dalam menguji kembali maupun dalam menyelesaikan soal yang dimaksud.

2. Wawancara

Setelah diadakan pemberian tes kemudian dianalisis hasilnya maka diambillah 6 orang siswa yang terdiri dari 2 siswa dengan nilai tertinggi, 2 siswa dengan nilai sedang dan 2 siswa dengan nilai terendah dalam setiap sekolah untuk dijadikan subjek penelitian. Tujuan wawancara ini adalah untuk membantu peneliti mencocokkan kebenaran jawaban yang

${ }^{8}$ UK Essays, "Students Performance In Rural And Urban Areas Education Essay," UKEssays.Com, November 2018, https://www.ukessays.com/essays/education/studentsperformance-in-rural-and-urban-areas-education-essay.php. 
telah diuraikan oleh siswa serta mengungkap faktor-faktor yang menjadi penyebab kesulitan siswa dalam menyelesaikan soal.

Prosedur pelaksanaan penelitian ini, secara garis besarnya antara lain: 1) Melakukan observasi ke masing-masing sekolah, 2) Menyediakan dan memvalidasi instrument yang akan digunakan, 3) Memberikan tes tertulis bentuk uraian sebanyak 6 nomor, 4) Menganailisis lembar jawaban siswa dan menyortir nilai siswa dari tertinggi hinggga terendah untuk memudahkan pengambilan subjek penelitian, 5) Menentukan subjek penelitian yang terdiri dari 2 siswa bernilai tertinggi, 2 siswa bernilai sedang dan 2 siswa bernilai paling rendah untuk masing-masing sekolah, 6) Melakukan wawancara kepada keenam subjek tersebut untuk mencocokkan jawaban yang telah mereka uraikan serta bertujuan mengungkap fakta yang menjadi kesulitan mereka dalam menyelesaikan soal, 7) Mendiskusikan dengan guru mata pelajaran matematika serta kepala sekolah mengenai kesulitan-kesulitan yang dialami siswa sehingga menyebabkan terjadinya kesalahan dalam menyelesaikan soal. Adapun teknik analisis data dalam penelitian ini sebagai berikut:

1. Reduksi data

Tahap awal dalam pengolahan data ini adalah reduksi data. Tujuannya adalah untuk merangkum, memilih dan membuat informasi yang ada menjadi lebih fokus sehingga mempermudah interpretasi data yang telah dikumpulkan. ${ }^{9}$

2. Penyajian Data

Data yang telah direduksi selanjutnya disusun untuk menghasilkan informasi yang dapat disimpulkan dan memiliki makna tertentu. Prosesnya dapat dilakukan dengan cara menampilkan dan membuat hubungan antar fenomena untuk memaknai apa yang sebenarnya terjadi dan apa yang perlu ditindaklanjuti untuk mencapai tujuan penelitian. Penyajian data yang baik dan jelas alur pikirnya merupakan hal yang sangat diharapakan oleh setiap peneliti. Penyajian data yang baik merupakan satu langkah penting menuju tercapainya analisis kualitatif yang valid dan handal ${ }^{10}$.

3. Menarik Kesimpulan atau Verifikasi

Penarikan kesimpulan menurut Miles \& Huberman hanyalah sebagian dari satu kegiatan dari konfigurasi yang utuh. Kesimpulan-kesimpulan juga diverifikasi selama penelitian berlangsung. Verifikasi itu mungkin sesingkat pemikiran kembali yang melintas dalam pikiran penganalisis

\footnotetext{
${ }^{9}$ Marzuki Ahmad and Dwi Putria Nasution, "Analisis Kualitatif Kemampuan Komunikasi Matematis Siswa Yang Diberi Pembelajaran Matematika Realistik," Jurnal Gantang 3, no. 2 (September 30, 2018): 88, https://doi.org/10.31629/jg.v3i2.471.

${ }^{10}$ Humas, "Penyajian Data dalam Penelitian Kualitatif," penalaran-unm.org, November 13, 2016, https://penalaran-unm.org/penyajian-data-dalam-penelitian-kualitatif/.
} 
(peneliti) selama ia menulis, suatu tinjauan ulang pada catatan-catatan lapangan, atau mungkin menjadi begitu seksama dan makan tenaga dengan peninjauan kembali serta tukar pikiran di antara teman sejawat untuk mengembangkan "kesepakatan intersubjektif" atau juga upayaupaya yang luas untuk menempatkan salinan suatu temuan dalam seperangkat data yang lain. Singkatnya, makna-makna yang muncul dari data yang lain harus diuji kebenarannya, kekokohannya, dan kecocokannya, yakni yang merupakan validitasnya ${ }^{11}$.

4. Pengecekan Keabsahan Data

Menurut Meleong untuk menentukan keabsahan data yang telah ditemukan, maka ada beberapa cara pemeriksaan antara lain: cara perpanjangan keikutsertaan, cara ketekunan pengamatan, cara triangulasi, cara pengecekan sejawat, cara kecukupan referensial, cara kajian kass negatif, cara pengecekan anggota, cara uraian rinci, dan terakhir cara auditing. Dalam penelitian ini menggunakan cara triangulasi dalam menentukan keabsahan data temuan. Pada penelitian ini jenis triangulasi yang digunakan adalah triangulasi sumber yakni membandingkan dan mengecek balik derajat kepercayaan suatu informasi yang diperoleh melalui waktu dan alat yang berbeda. Adapun triangulasi sumber yang dilakukan disini adalah membandingkan hasil pekerjaan siswa untuk setiap nomornya dengan hasil wawancara siswa yang bersangkutan ${ }^{12}$.

\section{Hasil dan Diskusi}

Dari hasil penelitian yang telah dilakukan, diperoleh beberapa temuan sebagai berikut:

Tabel 1. Kesalahan Siswa Hasil Triangulasi pada SMA di Perkotaan

\begin{tabular}{|c|c|c|}
\hline Nomor Soal & Data Temuan & $\begin{array}{c}\text { Subjek } \\
\text { Penelitian }\end{array}$ \\
\hline Nomor $1 \mathrm{a}$ & $\begin{array}{l}\text { a. Siswa yang tidak memahami secara } \\
\text { keseluruhan apa yang ditanyakan dan } \\
\text { bagaimana cara menyelesaikan soal } \\
\text { tersebut namun dapat menuliskan } \\
\text { jawaban yang sempurna karena hasil } \\
\text { contekan dari cakaran temannya } \\
\text { b. Siswa yang telah memahami apa yang } \\
\text { diketahui dan apa yang ditanyakan pada } \\
\text { soal tersebut hanya saja tidak mampu }\end{array}$ & $\begin{array}{l}\text { S6 SMA di } \\
\text { Kota }\end{array}$ \\
\hline
\end{tabular}




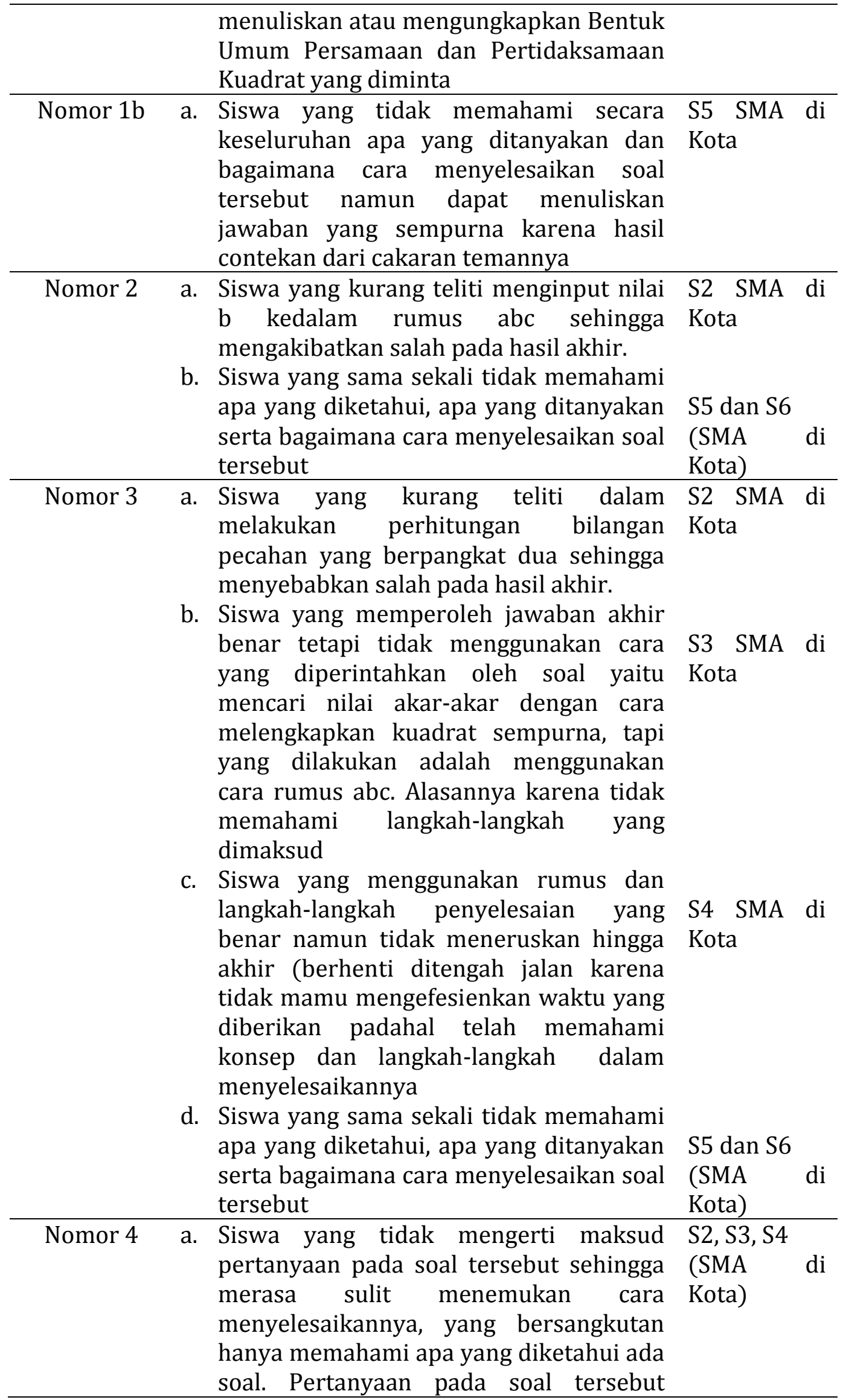




\begin{tabular}{|c|c|c|c|}
\hline & b. & $\begin{array}{l}\text { adalah "Hitunglah jumlah dan hasil kali } \\
\text { dari akar-akar persamaan } \\
x^{2}+10 x+25=0 \text { " } \\
\text { Siswa yang sama sekali tidak memahami } \\
\text { apa yang diketahui, apa yang ditanyakan } \\
\text { serta bagaimana cara menyelesaikan soal } \\
\text { tersebut }\end{array}$ & $\begin{array}{l}\text { S5 dan S6 } \\
\text { (SMA di } \\
\text { Kota) }\end{array}$ \\
\hline Nomor 5 & a. & $\begin{array}{l}\text { Siswa yang tidak mengerti maksud } \\
\text { pertanyaan pada soal tersebut sehingga } \\
\text { merasa sulit menemukan cara } \\
\text { menyelesaikannya yang bersangkutan } \\
\text { hanya memahami apa yang diketahui ada } \\
\text { soal. Pertanyaan pada soall tersebut } \\
\text { adalah "Carilah persamaan kuadrat baru } \\
\text { yang akar-akarnya } 2 \text { kali akar-akar dari } \\
\text { persamaan } x^{2}-5 x+3=0 \text { !" } \\
\text { Siswa yang sama sekali tidak memahami } \\
\text { apa yang diketahui, apa yang ditanyakan } \\
\text { serta bagaimana cara menyelesaikan soal } \\
\text { tersebut }\end{array}$ & $\begin{array}{l}\text { S3 dan S4 } \\
\text { (SMA di } \\
\text { Kota) }\end{array}$ \\
\hline No & a. & $\begin{array}{l}\text { Siswa yang tidak memahami secara } \\
\text { keseluruhan soal tersebut dengan alasan } \\
\text { belum pernah mendapatkan materinya } \\
\text { Siswa yang hanya lupa cara menentukan } \\
\text { HP dari suatu persamaan tapi telah } \\
\text { menahami apa yang diketahui dan apa } \\
\text { yang ditanyakan pada soal tersebut } \\
\text { Siswa yang sama sekali tidak memahami } \\
\text { apa yang diketahui, apa yang ditanyakan } \\
\text { serta bagaimana cara menyelesaikan soal } \\
\text { tersebut }\end{array}$ & $\begin{array}{l}\text { S5 dan S6 } \\
\text { (SMA di } \\
\text { Kota) }\end{array}$ \\
\hline Nom & a. & $\begin{array}{l}\text { Siswa yang tidak memahami secara } \\
\text { keseluruhan soal tersebut dengan alasan } \\
\text { belum pernah mendapatkan materinya } \\
\text { Siswa yang memahami konsep dan } \\
\text { langkah-langkah dalam melukiskan } \\
\text { grafik persamaan kuadrat yang diminta, } \\
\text { hanya saja tidak meneruskan karena } \\
\text { tidak mampu mengefesienkan waktu } \\
\text { yang diberikan } \\
\text { Siswa yang sama sekali tidak memahami } \\
\text { apa yang diketahui, apa yang ditanyakan } \\
\text { serta bagaimana cara menyelesaikan soal } \\
\text { tersebut }\end{array}$ & $\begin{array}{l}\text { S5 dan S6 } \\
\text { (SMA di } \\
\text { Kota) }\end{array}$ \\
\hline
\end{tabular}


Tabel 2. Kesalahan Siswa Hasil Triangulasi pada SMA di Pedesaan

\begin{tabular}{|c|c|c|}
\hline Nomor Soal & Data Temuan & $\begin{array}{c}\text { Subjek } \\
\text { Penelitian }\end{array}$ \\
\hline Nome & $\begin{array}{l}\text { a. Siswa yang tidak memahami secara } \\
\text { keseluruhan apa yang ditanyakan dan } \\
\text { bagaimana cara menyelesaikan soal } \\
\text { tersebut } \\
\text { b. Siswa yang telah memahami apa yang } \\
\text { diketahui dan apa yang ditanyakan pada } \\
\text { soal tersebut hanya saja tidak mampu } \\
\text { menuliskan atau mengungkapkan Bentuk } \\
\text { Umum Persamaan dan Pertidaksamaan } \\
\text { Kuadrat yang diminta }\end{array}$ & $\begin{array}{l}\text { S6 SMA di } \\
\text { Pedasaan }\end{array}$ \\
\hline Nom & $\begin{array}{l}\text { a. Siswa yang tidak memahami secara } \\
\text { keseluruhan apa yang ditanyakan dan } \\
\text { bagaimana cara menyelesaikan soal } \\
\text { tersebut }\end{array}$ & $\begin{array}{l}\text { S5 dan S6 } \\
\text { (SMA di } \\
\text { Pedesaan) }\end{array}$ \\
\hline No & $\begin{array}{l}\text { a. Siswa yang hanya mampu } \\
\text { mengungkapkan apa yang ditanyakan tapi } \\
\text { tidak memahami apa yang diketahui dan } \\
\text { bagaimana cara mencari akar-akar } \\
\text { persamaan kuadrat melalui rumus abc. } \\
\text { Siswa yang bersangkutan masih selalu } \\
\text { salah dalam menentukan setiap nilai a, b } \\
\text { dan c pada suatu persamaan terleih lagi } \\
\text { dalam melakukan operasi penjumlahan, } \\
\text { pengurangan atauun perkalian bilangan } \\
\text { bulat negatif } \\
\text { b. Siswa yang sama sekali tidak memahami } \\
\text { apa yang diketahui, apa yang ditanyakan } \\
\text { serta bagaimana cara menyelesaikan soal } \\
\text { tersebut } \\
\text { c. Siswa yang tidak menyelesaikan hingga } \\
\text { akhir karena tidak mampu melakukan } \\
\text { komputasi (operasi hitung bilangan } \\
\text { bulat), namun yang bersangkutan telah } \\
\text { memahami apa yang diketahui, apa yang } \\
\text { ditanyakan serta memahami rumus yang } \\
\text { harus digunakan. }\end{array}$ & $\begin{array}{l}\text { S4 SMA di } \\
\text { Pedesaan }\end{array}$ \\
\hline Nom & $\begin{array}{l}\text { a. Siswa yang sama sekali tidak memahami } \\
\text { apa yang diketahui, apa yang ditanyakan } \\
\text { serta bagaimana cara menyelesaikan soal } \\
\text { tersebut } \\
\text { b. Siswa yang hanya memahami apa yang } \\
\text { diketahui dan apa yang ditanyakan pada } \\
\text { soal tetapi tidak memahami rumus dan } \\
\text { langkah-langkah menyelesaikannya }\end{array}$ & $\begin{array}{l}\text { S3, S4, S6 } \\
\text { (SMA di } \\
\text { Pedesaan) }\end{array}$ \\
\hline
\end{tabular}




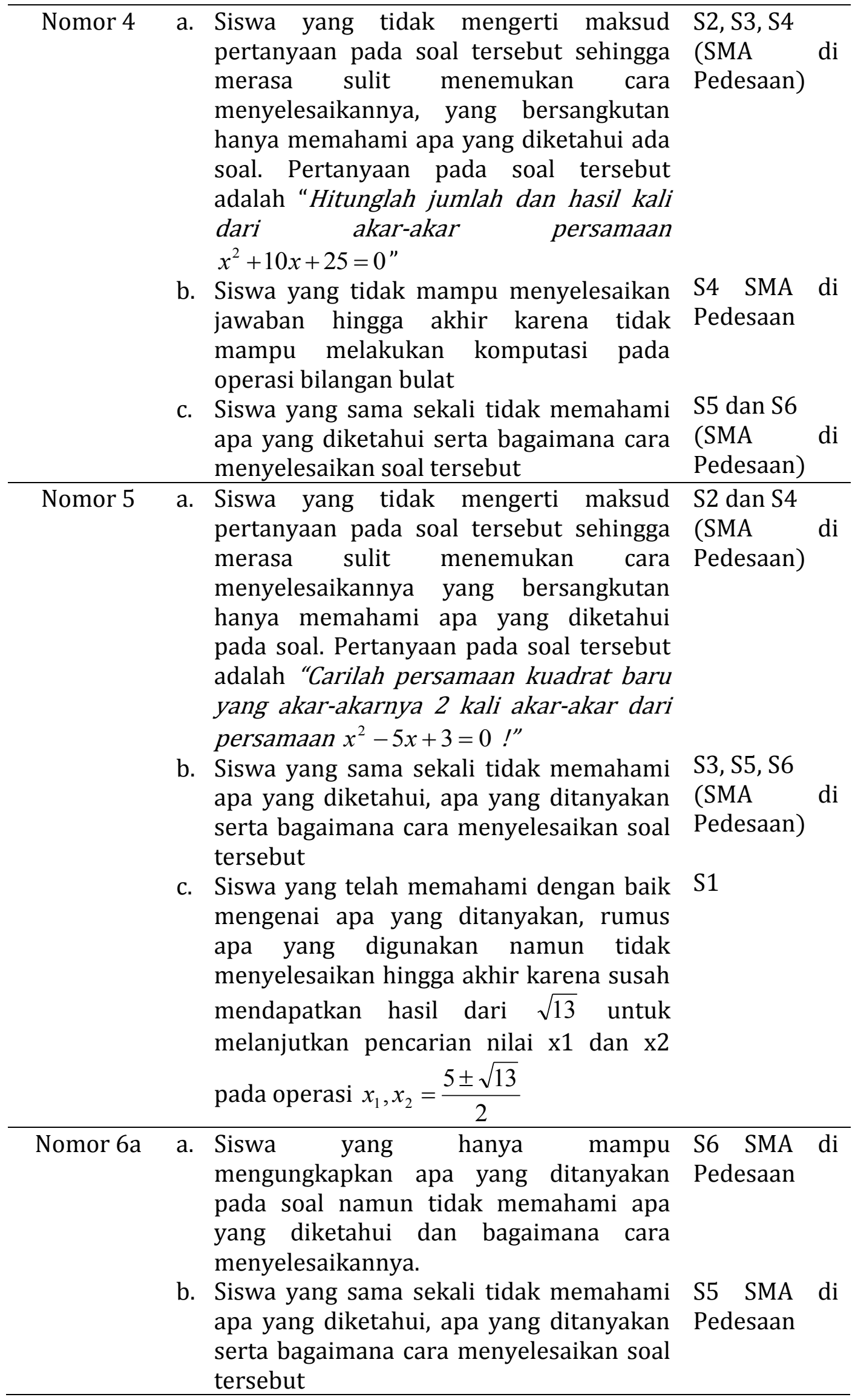




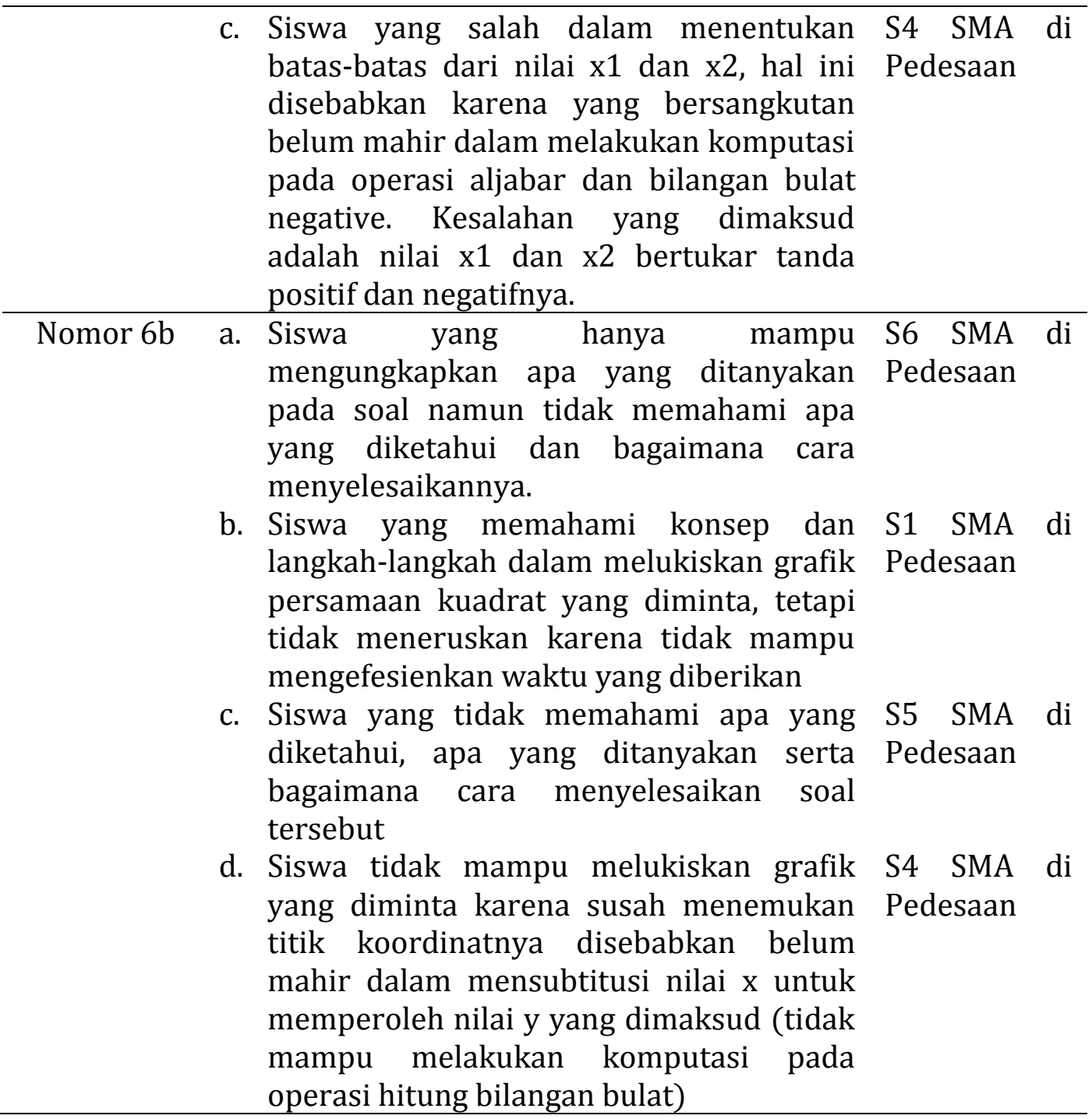

Sumber: Data Hasil Penelitian

Berdasarkan Tabel 1 dan Tabel 2 tersebut, terlihat bahwa kesulitan dalam menyelesaikan soal pada materi persamaan kuadrat dan pertidaksamaan kuadrat sama-sama dialami oleh siswa yang bersekolah di perkotaan dan di pedesaan. Hal ini sejalan dengan penelitian yang telah dilakukan oleh Agus Widi Agung ${ }^{13}$ dan Fitriati ${ }^{14}$ meskipun secara persentase pada beberapa indikator tertentu, tingkat kesalahan siswa di pedesaan lebih tinggi dibandingakn dengan siswa di perkotaan.

Jenis-jenis kesalahan yang dilakukan oleh siswa baik pada sekolah pedesaaan maupun sekolah perkotaan antara lain: 1) Kesalahan Pemahaman Konsep, 2) Kesalahan Prosedur Penyelesaian serta 3) Kesalahan dalam

${ }^{13}$ Agung, "Pengaruh Dana Bantuan Siswa Miskin Terhadap Prestasi Belajar pada Siswa Sekolah Menengah Pertama Se-Kabupaten Madiun Tahun 2011/2012.”

${ }^{14}$ Fitriati, "Studi Perbandingan Prestasi Belajar Antara Siswa Yang Berlatar Belakang Sosial Kota Dengan Desa Pada Madrasah Tsanawiyah (Mts) Manba'ul 'Ulum Kertak Hanyar." 
Melakukan Keterampilan komputasi (hitungan) atau keterampilan pengecekan kembali. Adapun persentase tingkat kesalahan masing-masing sekolah yakni pada SMA Perkotaan berturut-turut persentase kesalahan konsep, kesalahan prosedur dan kesalahan komputasi/hitungan adalah 30,30\%; 40,91\% dan 28,79\% dari total 66 kali ditemukan kesalahan oleh semua subjek. Sementara persentase tingkat kesalahan yang ditemukan pada SMA Pedesaan berturut-turut untuk kesalahan konsep, kesalahan prosedur dan kesalahan komputasi/hitungan adalah 32,26\%, 33,87\% dan 33,87\% dari total 62 kali ditemukan kesalahan oleh semua subjek.

Berdasarkan hal tersebut, nampak bahwa kesalahan yang paling tertinggi dan sering terjadi pada SMA Perkotaan adalah kesalahan prosedur dalam menyelesaikan soal, setelah itu kesalahan pemahaman konsep dan selanjutnya kesalahan melakukan komputasi/hitungan. Sementara pada SMA Pedesaan ditemukan bahwa kesalahan prosedur dalam menyelesaikan soal sama tingginya kesalahan melakukan komputasi/hitungan dan beda tipis dengan kesalahan pemahaman konsep. Lebih lanjut, Kesalahan konsep dan komputasi/hitungan siswa yang bersekolah di perkotaan lebih rendah daripada siswa yang bersekolah di pedesaan. Hal ini disebabkan siswa di perkotaan memiliki kesempatan dan fasilitas yang jauh lebih luas dan lengkap dalam mendukung pembelajarannya dibandingkan dengan siswa yang bersekolah di pedesaan. Hal ini sejalan dengan yang dikemukakan dalam UK Essays ${ }^{15}$.

Hal-hal yang menjadi faktor penyebab terjadinya kesalahan-kesalahan dalam menyelesaikan soal matematika materi Persamaan Kuadrat dan Pertidaksamaan Kuadrat pada SMA Perkotaan adalah:

1. Siswa tidak menghafal dan tidak memahami rumus yang diminta.

2. Siswa kurang teliti dalam mesubstitusi nilai kedalam rumus sehingga menyebabkan hasil akhir salah.

3. Siswa tidak mahir menggunakan cara melengkapkan kuadrat sempurna karena gurunya jarang mempraktekkan, yang sering-sering dilakukan guru hanya pemfaktoran dan menentukan akar-akar melalui rumus abc.

4. Siswa tidak memahami maksud dari pertanyaan pada soal yang disebabkan karena mungkin guru jarang atau bahkan tidak pernah memberikan contoh soal/pertanyaan seperti itu.

5. Siswa hanya benar-benar lupa dengan rumus yang harus digunakan padahal sebenarnya yang bersangkutan telah memahami alur penyelesaiannya.

6. Siswa yang bersangkutan tidak pernah mendapat materi yang dimaksud disebabkan karena tidak hadir saat materi diajarkan.

\footnotetext{
${ }^{15}$ Essays, "Students Performance In Rural And Urban Areas Education Essay."
} 
7. Siswa tidak mampu melakukan operasi hitungan dengan cepat (tepat waktu) sehingga tidak menyelesaikan hingga tuntas.

8. Adanya pendapat siswa yang mengatakan bahwa matematika itu susah dan membosankan

9. Adanya pendapat siswa yang mengatakan bahwa cara mengajar guru terlalu cepat serta memiliki suara/vocal yang kecil sehingga siswa merasa sulit mengikutinya.

Faktor-faktor penyebab terjadinya kesalahan siswa dalam menyelesaikan soal materi persamaan dam pertidaksamaan kuadrat pada SMA Pedesaan sebagai berikut:

1. Siswa sama sekali tidak memahami bagaimana cara menentukan masingmasing nilai $a, b$, dan $c$ pada suatu persamaan kuadrat.

2. Siswa tidak memahami apapun, kebanyakan diam, suka menyendiri, merasa diri miskin dan dicuekin sehingga motivasi belajar hampir tidak ada

3. Siswa hanya mampu mengungkapkan apa yang ditanyakan pada soal tapi tidak memahami apa yang diketahui, tidak tau menggunakan langkah apa serta tidak memahami cara menghitung/mengoperasikannya.

4. Siswa tidak mahir dalam mengoperasikan perkalian bilangan bulat negatif.

5. Siswa masih lemah dalam mensubtitusi nilai $\mathrm{x}$ untuk menemukan nilai y dari suatu persamaan karena tidak mahir dalam pengoperasian penjumlahan dan pengurangan bilangan bulat

6. Siswa tidak mahir mengoperasikan penjumlahan dan pengurangan bilangan bulat sehingga tanda untuk masing-masing nilai x1 dan x2 tertukar

7. Siswa merasa bahwa matematika itu sulit, membosankan dan cara mengajar guru tidak menarik.

8. Siswa yang bersangkutan tidak pernah mendapat materi yang dimaksud disebabkan karena tidak hadir saat materi diajarkan.

9. Siswa merasa diri bodoh dalam belajar matematika.

Faktor-faktor yang diutarakan tersebut adalah bersumber dari hasil wawancara kepada siswa yang telah diambil sebagai subjek pada masingmasing sekolah. Adapun faktor lain yang menjadi penyebab berdasarkan informasi tambahan oleh Guru Mata Pelajaran Matematika dan Kepala Sekolah adalah bahwa pada dasarnya siswa sendiri tidaklah memahami konsep dasar tentang perhitungan bilangan bulat dan bilangan pecahan yang sebagaimana telah diajarkan pada bangku Sekolah Dasar sehingga sangat susah ketika diberikan materi persamaan kuadrat dan pertidaksamaan kuadrat, selain itu lemahnya hafalan siswa terkait perkalian. Hal ini sejalan dengan hasil penelitian yang telah dilakukan Andi Ika Prasasti bahwa salah satu kesulitan siswa dalam menggunakan konsep matematika adalah 
ketidakmampuan siswa dalam menyatakan arti dan istilah yang mewakili konsep tertentu. ${ }^{16} \mathrm{Hal}$ ini menjadi problem besar yang dirasakan oleh guru pada jenjang SMA karena harus mengulang mengajarkan materi dasar yang sama sekali diluar kompetansi pada silabus sementara waktu tiap kompetensi inti sangatlah terbatas, terkecuali jika diadakan penambahan jam pelajaran.

Menindaklanjuti faktor-faktor tersebut, peneliti langsung mengadakan diskusi dengan kepala sekolah serta guru mata pelajaran matematika pada masing-masing sekolah dalam bentuk FGD (Focus Group Discussion) untuk membahas solusi dari permasalahan tersebut. Beberapa hal yang menjadi poin penting dari hasil FGD antara lain:

1. Menyarankan dan memberikan contoh kepada guru matematika agar mampu menggunakan beberapa strategi mengajar yang bersifat kontruktifis seperti penemuan terbimbing, open-ended, problem solving, problem posing, pembelajaran berbasis proyek, pendekatan saintifik, dan lain-lain. Hal ini bertujuan untuk meminimalisir metode ceramah yang selalu digunakan oleh guru sehingga membuat siswa merasa bosan.

2. Menyarankan kepada guru agar tetap mengulang-ulang materi dasar seperti penjumlahan, pengurangan, perkalian, pembagian bilangan bulat dan pecahan walaupun sama sekali tidak ada dalam kompetensi, akan tetapi sangat berpengaruh kepada materi persamaan kuadrat dan pertidaksamaan kuadrat ataupun materi lainnya. Kalau perlu diberikan jam tambahan untuk matematika

3. Mendemonstrasikan teknik menguasai operasi bilangan bulat dan pecahan dengan mudah dan menarik.

4. Menyarankan dan mendemonstrasikan kepada guru mengenai cara yang diajarkan kepada siswa untuk menguasai materi persamaan kuadrat dan pertidaksamaan kuadrat dengan mudah, seperti strategi hafalan rumus, strategi CTS : Catatan Tulis dan Susun, Strategi Peta Konsep (Maind Mapping)

5. Menyarankan kepada guru agar sesering mungkin memberikan pujian atas pekerjaan siswa dalam bentuk ucapan positif atau berupa hadiah menarik sehingga mereka termotivasi untuk belajar matematika

6. Menyarankan kepada guru agar sesering mungkin mampu mengambil hati para siswa, tidak hanya bertindak sebagai guru melainkan juga bertindak sebagai orang tua dan kadang bertindak sebagai teman siswa. Dengan tujuan agar hubungan antara guru dan siswa semakin harmonis serta siswa merasa diperhatikan sehingga mampu mencurahkan kesulitan yang dialami. Dengan demikian guru merasa mudah untuk memberi masukan dan solusi.

\footnotetext{
${ }^{16}$ Abrar, "Kesulitan Siswa SMP Belajar Konsep Dan Prinsip Dalam Matematika."
} 
7. Menyarankan kepada guru untuk konsisten dalam mengajar maupun mendidik baik berupa disiplin waktu maupun konsisten pada janji yang pernah disepakati oleh siswa berupa teknik penilaian, dan sebagainya.

8. Menyarankan kepada Kepala Sekolah untuk memberikan reward kepada guru-guru yang tekun, disiplin dan mampu meningkatkan hasil belajar siswanya.

9. Menyarankan kepada Kepala Sekolah dan Guru agar mereka mensupport para siswa yang senantiasa mengikuti Bimbingan Belajar di tempattempat kursus lainnya.

\section{Kesimpulan}

Analisis kesalahan siswa SMA di pedesaan dan perkotaan telah dilakukan. Dari hasil penelitian tersebut dapat disimpulkan sebagai berikut:

1. Kesalahan dalam menyelasaikan soal matematika materi persamaan kuadrat dan pertidaksamaan kuadrat tidak hanya ditemukan pada SMA Pedesaan saja melainkan juga ditemukan pada SMA Perkotaan. Adapun kesalahan yang dimaksud terdiri dari: 1) Kesalahan Pemahaman Konsep, 2) Kesalahan Prosedur Penyelesaian dan 3) Kesalahan Keterampilan komputasi (hitungan) atau keterampilan pengecekan kembali.

2. Persentase kesalahan yang dilakukan siswa pada SMA Perkotaan antara lain: 1) Kesalahan Pemahaman Konsep mencapai 30,30\%; 2) Kesalahan Prosedur Penyelesaian mencapai 40,91\% serta 3) Kesalahan Keterampilan Komputasi mencapai 28,79\%. Sementara Persentase kesalahan yang dilakukan siswa pada SMA Pedesaan antara lain: 1) Kesalahan Pemahaman Konsep mencapai 32,26\%; 2) Kesalahan Prosedur Penyelesaian mencapai 33,87\% serta 3) Kesalahan Keterampilan Komputasi juga mencapai $33,87 \%$.

3. Faktor penyebab terjadinya kesalahan siswa dalam menyelesaikan soal matematika materi persamaan kuadrat dan pertidaksamaan kuadrat, umumnya disebabkan karena siswa kurang memahami materi dasar seperti operasi bilangan bulat dan pecahan, operasi bentuk akar, dan lainlain. Selain dari itu kurangnya minat dan motivasi siswa untuk belajar matematika, karena meraka selalu menganggap bahwa matematika tersebut sangat susah dan membosankan. Menindaklanjuti hal tersebut, peneliti telah melakukan diskusi dalam bentuk FGD (Focus Grou Discussion) bersama masing-masing Kepala Sekolah dan Guru Mata Pelajaran Matematika untuk membahas solusi mengenai kesulitan siswa dalam menyelesaikan soal matematika materi persamaan kuadrat dan pertidaksamaan kuadrat. 


\section{Daftar Pustaka}

Abrar, Andi Ika Prasasti. "Kesulitan Siswa SMP Belajar Konsep Dan Prinsip Dalam Matematika." Al-Khwarizmi: Jurnal Pendidikan Matematika dan IImu Pengetahuan Alam 2, no. 1 (2014): 59-68. https://doi.org/10.24256/jpmipa.v2i1.102.

Agung, Agus Widi. "Pengaruh Dana Bantuan Siswa Miskin Terhadap Prestasi Belajar pada Siswa Sekolah Menengah Pertama Se-Kabupaten Madiun Tahun 2011/2012." Thesis, UNS (Sebelas Maret University), 2012. https://digilib.uns.ac.id/dokumen/25582/Pengaruh-Dana-BantuanSiswa-Miskin-Terhadap-Prestasi-Belajar-pada-Siswa-SekolahMenengah-Pertama-Se-Kabupaten-Madiun-Tahun-20112012.

Ahmad, Marzuki, and Dwi Putria Nasution. "Analisis Kualitatif Kemampuan Komunikasi Matematis Siswa Yang Diberi Pembelajaran Matematika Realistik." Jurnal Gantang 3, no. 2 (September 30, 2018): 83-95. https://doi.org/10.31629/jg.v3i2.471.

Carraher, David. "Beyond 'Blaming the Victim' and 'Standing in Awe of Noble Savages': A Response to 'Revisiting Lave's "Cognition in Practice."”' Educational Studies in Mathematics 69 (September 1, 2008): 23-32. https://doi.org/10.1007/s10649-008-9126-4.

Darwis, Rahma Hidayati. "Eksplorasi Hasil Belajar, Aktifitas Siswa Dan Respon Siswa Pada Penerapan Metode Tutor Sebaya Dan Metode Kerja Kelompok Dalam Pembelajaran Remedial Matematika Meteri Trigonometri Pada Kelas XI SAP SMK Negeri 1 Watampone." PhD Thesis, Thesis. Tidak Diterbitkan. Makassar: Pascasarjana Universitas Negeri Makassar, 2014.

Essays, UK. "Students Performance In Rural And Urban Areas Education Essay." UKEssays.Com, November 2018. https://www.ukessays.com/essays/education/studentsperformance-in-rural-and-urban-areas-education-essay.php.

Fitriati, Fitriati. "Studi Perbandingan Prestasi Belajar Antara Siswa Yang Berlatar Belakang Sosial Kota Dengan Desa Pada Madrasah Tsanawiyah (Mts) Manba'ul 'Ulum Kertak Hanyar." Skripsi, UIN Antasari Banjarmasin, 2013. https://idr.uin-antasari.ac.id/2769/.

Halim Malik. "Penelitian Kualitatif." KOMPASIANA. Accessed March 27, 2020. https://www.kompasiana.com/unik/55008172a333114e75510f2c/p enelitian-kualitatif.

Humas. "Penyajian Data dalam Penelitian Kualitatif." penalaran-unm.org, November 13, 2016. https://penalaran-unm.org/penyajian-datadalam-penelitian-kualitatif/.

J.Moleong, Lexi. Metodelogi Penelitian Kualitatif. Bandung: PT Remaja Rosdakarya, 2015.

Soedjadi, R. Kiat Pendidikan Matematika Di Indonesia. Jakarta: Dirjen Dikti Depdikbud, 2000.

Tirtarahardja, Umar, and La Sulo. Pengantar Pendidikan. Cet. 2. Rineka Cipta, 2005. 